\title{
Histamine induced bronchoconstriction and end tidal inspiratory activity in man
}

\author{
N E L Meessen, C P M van der Grinten, S C M Luijendijk, H Th M Folgering
}

\begin{abstract}
Background - End tidal inspiratory activity (ETIA) in diaphragm and parasternal intercostal muscles can be evoked in man and in animals by administration of histamine. Exacerbations of asthma and administration of histamine are often accompanied by hyperinflation. The aims of the study were to determine (1) the magnitude of ETIA in response to histamine in man, (2) the relative contributions of chemical and mechanical stimulation of airway receptors to ETIA, and (3) the importance of ETIA to hyperinflation.
\end{abstract}

Methods - The effects of inhalation of histamine on the electrical activities of the diaphragm and parasternal intercostal muscles measured with surface electrodes were studied in 21 subjects. The experiments were repeated after inhalation of $600 \mu \mathrm{g}$ of salbutamol to prevent histamine induced bronchoconstriction and concomitant mechanical stimulation of airway receptors. Subjects were connected to a closed breathing circuit to measure the changes in functional residual capacity (FRC) for the different experiments.

Results - The mean values of histamine induced ETIA were $60.6 \%$ and $46.9 \%$ of peak inspiratory activities during control conditions for the diaphragm and intercostal muscles, respectively. After salbutamol histamine induced ETIA was reduced to about one quarter of pre-salbutamol values. FRC increased by $427 \mathrm{ml}$ as a result of inhalation of histamine, but after salbutamol this increase was only $53 \mathrm{ml}$. The data for ETIA and FRC were interpreted as indicating that the contributions of airflow limitation and ETIA to histamine induced hyperinflation are comparable.

Conclusions - Histamine is a forceful stimulus for inducing ETIA. Both chemical and mechanical stimulation of airway receptors contribute to evoke ETIA, of which the contribution of mechanical stimulation is the more important one. ETIA contributes substantially to histamine induced hyperinflation.

(Thorax 1996;51:1192-1198)

Keywords: end tidal inspiratory activity, histamine, EMG, lung receptors, $\beta_{2}$ agonist, bronchoconstriction.

Correspondence to:

Received 3 January 1995

Returned to authors

29 June 1995

Revised version received

23 April 1996

Accepted for publication

30 May 1996

EMG activity of inspiratory muscles at the end of expiration has been observed in response to administration of histamine both in animals ${ }^{12}$ and man. ${ }^{34}$ We have shown in cats that this so called end tidal inspiratory activity (ETIA) is a vagal reflex activity which is due to stimulation of rapidly adapting pulmonary receptors. ${ }^{25}$ Rapidly adapting pulmonary receptors can be stimulated by histamine in cats, ${ }^{6}$ dogs, ${ }^{7}$ and rabbits. ${ }^{8}$ It is not known whether they are stimulated by histamine by direct chemical effects or by indirect mechanical effects due to bronchoconstriction, or by a combination of both. ${ }^{7-12}$

Exacerbations of asthma and administration of histamine are often accompanied by hyperinflation. ${ }^{13-15}$ Although both bronchoconstriction and ETIA are accepted as causes of hyperinflation in bronchial asthma, ${ }^{16}$ it has not yet been shown which is more important. The aims of the present study were therefore to determine (1) the magnitude of ETIA in response to histamine in man, (2) the relative contributions of chemical and mechanical stimulation of airway receptors to ETIA, and (3) the importance of ETIA to hyperinflation. To this end, experiments were performed on human subjects who were challenged with histamine both before and after administration of the $\beta_{2}$ agonist salbutamol. Salbutamol provides protection against bronchoconstriction caused by different stimuli such as histamine, ${ }^{1718}$ so in the latter experiment histamine induced bronchoconstriction was largely prevented.

\section{Methods}

SUBJECTS

Twenty one subjects (nine men) of age range 14-62 years participated in the study. Characteristics of the subjects are presented in table 1. Informed consent was obtained from all subjects who were naive with respect to the aims of the study which was approved by the ethical committee of the hospital.

MEASUREMENT OF RESPIRATORY MUSCLE FUNCTION

Subjects were connected to a closed breathing circuit (fig 1 ) by a mouthpiece and oxygen was

Table 1 Mean (SE) characteristics of the subjects $(n=21)$

\begin{tabular}{|c|c|}
\hline Mean age (years) & $32.5(2.5)$ \\
\hline M:F & $9: 12$ \\
\hline Height $(\mathrm{cm})$ & $174.9(1.5)$ \\
\hline Weight (kg) & $71.7(2.6)$ \\
\hline $\mathrm{FEV}_{1}(1)$ & $3.6(0.19)$ \\
\hline $\mathrm{FEV}_{1}$ (\%pred) & $94.7(3.2)$ \\
\hline $\mathrm{FEV}_{1} / \mathrm{FVC}(\%)$ & $78.9(1.9)$ \\
\hline FRCpred(1) & $3.1(0.08)$ \\
\hline $\mathrm{Rrs}_{6}\left(\mathrm{hPa} .1^{\prime \prime} . \mathrm{s}\right)$ & $3.5(0.36)$ \\
\hline
\end{tabular}

$\mathrm{FEV}_{1}=$ forced expiratory volume in one second; $\mathrm{FVC}=$ forced expiratory vital capacity; $\mathrm{Rrs}_{6}=$ airway resistance determined at $6 \mathrm{~Hz}$ by forced oscillation technique.
expiratory vital capacity; $\mathrm{Rrs}_{6}=$ airway 


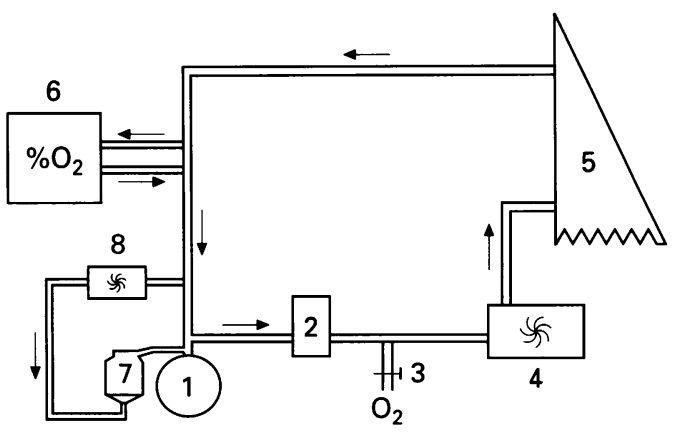

Figure 1 Diagram of the breathing circuit. $1=$ subject connected to the circuit by a mouthpiece; $2=$ soda lime; $3=$ port for supplying oxygen; $4=$ pump for bias flow; $5=$ wedge spirometer; $6=$ oxygen analyser; $7=$ nebuliser; $8=$ pump generating flow for aerosol. The equipment dead space of the circuit was $49 \mathrm{ml}$.

supplied to maintain the oxygen concentration in the circuit constant $(21 \%)$. Gas was sampled continuously from the circuit for the measurement of the oxygen concentration (Taylor Servomex) and subsequently fed back into the system (fig 1). A pump maintained a constant bias flow in the circuit of at least $120 \mathrm{l} / \mathrm{min}$ which prevented rebreathing of $\mathrm{CO}_{2}$. Exhaled $\mathrm{CO}_{2}$ was absorbed by soda lime. An aerosol of saline or histamine could be delivered by a jet nebuliser (DeVilbiss 646) which was connected to the circuit near the mouthpiece (fig 1). The calibrated output of the nebuliser was $0.13 \mathrm{ml} /$ min.

The electrical activities of the diaphragm and intercostal muscles were obtained from two pairs of electrodes, each pair consisting of two silver discs of $7 \mathrm{~mm}$ diameter which were glued to the skin, $2 \mathrm{~cm}$ apart. The electromyogram (EMG) of the intercostal muscles was obtained from electrodes placed parasternally in the left second intercostal space. The EMG of the diaphragm was obtained from another pair of electrodes placed between the mid-clavicular and mid-axillary line in the seventh or eighth right intercostal space. The raw EMG activities were amplified, filtered $(200-1200 \mathrm{~Hz})$, rectified, and fed into a leaky integrator with a time constant of $50 \mathrm{~ms}$ (Neurolog, Digitimer). The integrated activities of the diaphragm and intercostal muscles, the volume signal of the wedge spirometer, and the oxygen concentration of the gas in the breathing circuit were recorded with a multichannel $\mathrm{X}$ - $\mathrm{t}$ recorder (Kipp, The Netherlands). The responses of the diaphragm, intercostal muscles, and functional residual capacity (FRC) to inhalation of histamine were studied from these recordings. EMG activities were also monitored by an audio monitor.

All subjects were tested in the sitting position. They were seated in a relaxed posture and were asked to remain in that position until the end of the recording. Thus, with good cooperation from our subjects we were able to minimise the effect of the postural muscles on recorded EMG activities. To divert their attention from breathing they were asked to concentrate on a poster placed in front of them.
EXPERIMENTAL PROTOCOL

The provocative concentration of histamine $\left(\mathrm{PC}_{20}\right)$ at which the forced expiratory volume in one second $\left(\mathrm{FEV}_{1}\right)$ fell by $20 \%$ of the prechallenge value was determined on day 1 with a histamine challenge test using the method of Hargreave et al. ${ }^{19}$ On day 2 the effects of inhaling one single concentration of histamine on EMGs of the diaphragm and intercostal muscles and on the FRC were studied. This concentration was the one at which on day 1 $\mathrm{FEV}_{1}$ had fallen by $20 \%$ or more or, in case of a non-responsive subject, the highest concentration used on day $1(\geq 8 \mathrm{mg} / \mathrm{ml})$. After the subject had been connected to the breathing circuit the recording was started. The recording included at least five stable control breaths and continued for the two minutes of histamine inhalation and a further 1.5 minutes thereafter. Subsequently, $600 \mu \mathrm{g}$ of salbutamol (Ventolin) was administered by a standard metered dose inhaler. Fifteen minutes later the single dose histamine test was repeated. In order to evaluate the effects of histamine and salbutamol on airway mechanics, respiratory resistance and $\mathrm{FEV}_{1}$ were determined on four occasions: before histamine (control), after inhalation of histamine, 15 minutes after inhalation of salbutamol, and after a subsequent inhalation of histamine.

\section{PULMONARY FUNCTION MEASUREMENTS}

Changes in FRC ( $\triangle F R C)$ in response to histamine were calculated from the spirogram. Forced vital capacity (FVC) and $\mathrm{FEV}_{1}$ were obtained by standard spirometric measurements (Fukuda Sangyo). All values were related to the reference values of the European Community for Coal and Steel. ${ }^{20}$

Respiratory resistance was determined by means of the forced oscillation technique which has been described in detail elsewhere. ${ }^{21}$ It has been reported that respiratory resistance measured at low frequencies correlates well with airway resistance. ${ }^{22}$ In the present study the resistance at $6 \mathrm{~Hz}$ was used $\left(\mathrm{Rrs}_{6}\right)$.

\section{DATA ANALYSIS}

Mean values of end tidal EMG activity and of peak EMG activity were calculated from five consecutive breaths recorded about 60 seconds after the inhalation of histamine had been stopped. These mean values will be referred to as $\mathrm{EMGet}_{\mathrm{HIST}}$ and $\mathrm{EMGpk}_{\mathrm{HIST}}$, respectively. In a similar way we determined EMGpk CTRL $_{\text {from }}$ the recordings of five consecutive control breaths of the same experiment taken from the last part of the control period. ETIA is represented by EMGet. In order to minimise the effects of instrumental, intersubject, and intrasubject scatter in the measured EMG activity ETIA was expressed as a percentage of EMGpk $\mathrm{CTRL}_{\mathrm{CTL}}$ and, for the same reason, $\mathrm{EMGpk}_{\mathrm{HIST}}$ was also expressed as a percentage of EMGpk $\mathrm{ETRI}_{\mathrm{CTR}}$

Changes in FRC were determined from the difference in FRC between the same groups of breaths, five control breaths, and five breaths 


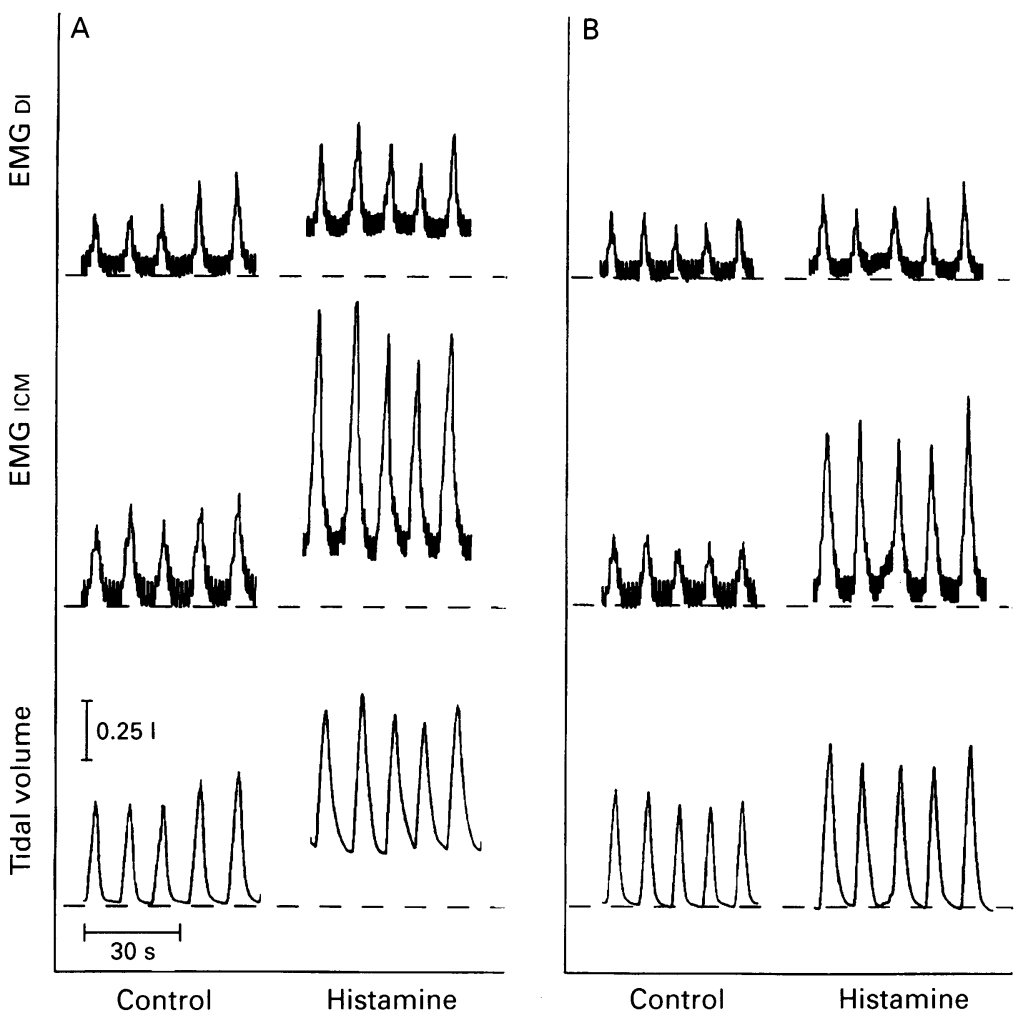

Figure 2 Representative recordings of integrated electromyograms of the diaphragm (EMGDI) and of parasternal intercostal muscles (EMGICM) and of the corresponding changes in spirometer volume (inspiration up, expiration down) in response to histamine. $A$ histamine concentration was applied which produced a fall in $F E V_{1}$ of more than $20 \%$ (A) Breaths during control and after inhalation of histamine. End tidal inspiratory activity is induced in EMGDI and EMGICM in response to histamine and FRC is increased. (B) After inhalation of $600 \mu \mathrm{g}$ salbutamol the experiment was repeated with the same histamine concentration. End tidal levels of both EMGs are increased only slightly in response to histamine and in this example FRC did not change at all.

60 seconds after the inhalation of histamine had been stopped. A mismatch between oxygen supply and oxygen uptake will cause the baseline of the spirometer signal to drift one way or the other which would affect the results for $\triangle F R C$. The shift in the baseline of the spirometer signal is proportional to the deviation of the oxygen concentration from $21 \%$. The relationship between these two factors was determined experimentally by adding a known amount of pure oxygen to the system and by reading the corresponding change in oxygen concentration. With the help of this relationship we have corrected the raw data for $\triangle F R C$ for the aforementioned oxygen concentration related shift of the spirometer signal. The inaccuracy of the correction was $\pm 6 \mathrm{ml}$. This error adds to the overall random error in the determination of $\triangle F R C$.

All values reported are means (SE). Unless otherwise indicated, differences were evaluated

Table 2 Mean (SE) responses of FRC, FEV and Rrs $_{6}$ before and after salbutamol $(n=21)$

\begin{tabular}{|c|c|c|c|c|}
\hline & \multicolumn{2}{|c|}{ Before salbutamol } & \multicolumn{2}{|c|}{ After salbutamol } \\
\hline & Control & Histamine & Control & Histamine \\
\hline 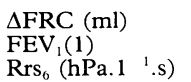 & $\begin{array}{l}3.6(0.19) \\
3.5(0.36)\end{array}$ & $\begin{array}{l}427(67) \\
2.8(0.21)^{* * *} \\
5.9(0.48)^{* * *}\end{array}$ & $\begin{array}{l}3.7(0.21) \\
2.8(0.22)\end{array}$ & $\begin{array}{l}53(16) \\
3.5(0.23)^{*} \\
3.3(0.23)^{* *}\end{array}$ \\
\hline
\end{tabular}

$\triangle \mathrm{FRC}=$ change in functional residual capacity in response to histamine; $\mathrm{FEV}_{1}=$ forced expiratory volume in one second; $\mathrm{Rrs}_{6}=$ airway resistance determined at $6 \mathrm{~Hz} .{ }^{*} \mathrm{p}<0.05$; ${ }^{* *} \mathrm{p}<0.01$; ${ }_{* * *}$ p $<0.001$ control versus histamine.

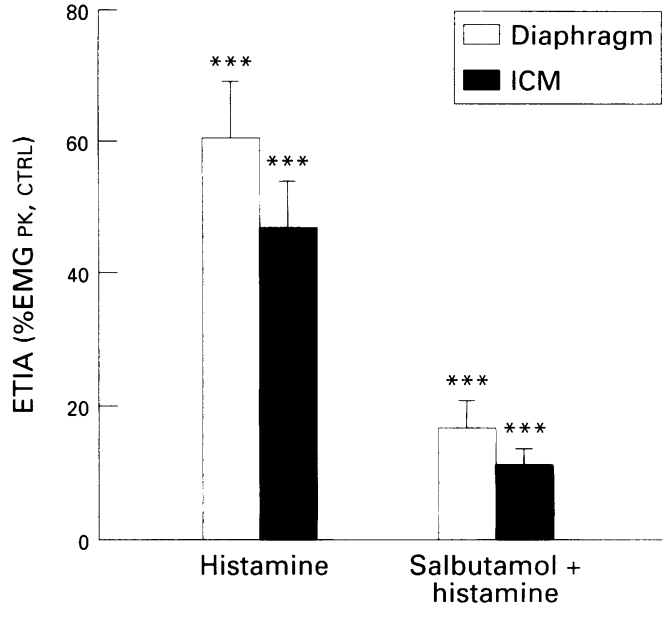

Figure 3 Effects of inhalation of histamine on end tidal inspiratory activity (ETIA) in the diaphragm and intercostal muscles (ICM). ETIA is expressed as a percentage of mean peak EMG activity of corresponding control breaths. After inhalation of $600 \mu \mathrm{g}$ salbutamol the histamine induced ETIA had decreased significantly ( $p<0.01$ and $p<0.001$ for the diaphragm and intercostal muscles, respectively) compared with values before salbutamol. Data represent mean values obtained from 21 subjects. Error bars indicate $1 S E . * * p<0.001$ compared with control values (Wilcoxon's test for paired observations).

for statistical significance using the Wilcoxon's test for paired observations. A p value of $<0.05$ was considered to be significant. Statistical analysis was performed using the statistical software package SPSS/PC + (SPSS Inc, Chicago, Illinois).

\section{Results}

EFFECTS OF HISTAMINE ON EMG AND FRC

Figure 2 shows the results for one subject's recordings of integrated electrical activities of the diaphragm and intercostal muscles and of the corresponding changes in lung volume. The recordings show that, before inhalation of salbutamol, ETIA is evoked in the diaphragm and in the intercostal muscles in response to histamine as end tidal EMGs do not return to baseline levels (fig 2A). At the same time FRC is increased. After administration of salbutamol inhalation of histamine evokes hardly any ETIA and FRC did not change at all in this subject (fig 2B).

Before inhalation of salbutamol mean (SE) values of histamine induced ETIA obtained from 21 subjects were $60.6(8.5) \%$ and 46.9 (7.0)\% of $\mathrm{EMGpk}_{\mathrm{CTRL}}$ for the diaphragm and intercostal muscles, respectively (fig 3). The mean increase in FRC ( $\triangle \mathrm{FRC})$ was 427 (67) $\mathrm{ml}$ or $13.7(2.1) \%$ of FRC predicted (table 2, fig $4)$. In response to histamine, peak inspiratory EMG activity increased to 375 (46)\% and 364 (49) $\%$ of $\mathrm{EMGpk}_{\mathrm{CTRL}}$ for the diaphragm and intercostal muscles, respectively (fig 5).

After inhalation of salbutamol histamine induced ETIA was $16.6(4.1) \%$ and 10.9 (2.7)\% for the diaphragm and intercostal muscles, respectively (fig 3). Histamine induced ETIA was significantly lower after inhalation of salbutamol compared with pre-salbutamol values 


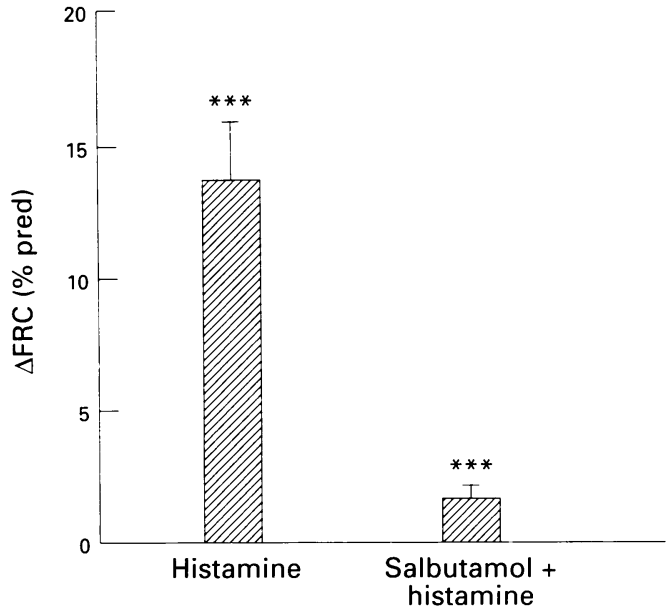

Figure 4 Effects of histamine on functional residual capacity (FRC) before and after inhalation of $600 \mu \mathrm{g}$ salbutamol. Changes in FRC are presented as percentage of FRC predicted. Data represent means obtained from 21 subjects. Error bars indicate 1 SE. ***p $<0.001$ compared with values before salbutamol (Wilcoxon's test for paired observations).

( $\mathrm{p}<0.01$ and $\mathrm{p}<0.001$ for the diaphragm and intercostal muscles, respectively). After salbutamol FRC was only slightly though significantly $(p<0.001)$ elevated in response to histamine. The mean increase in FRC was 53 (16) $\mathrm{ml}$ or $1.7(0.5) \%$ of FRC predicted (table

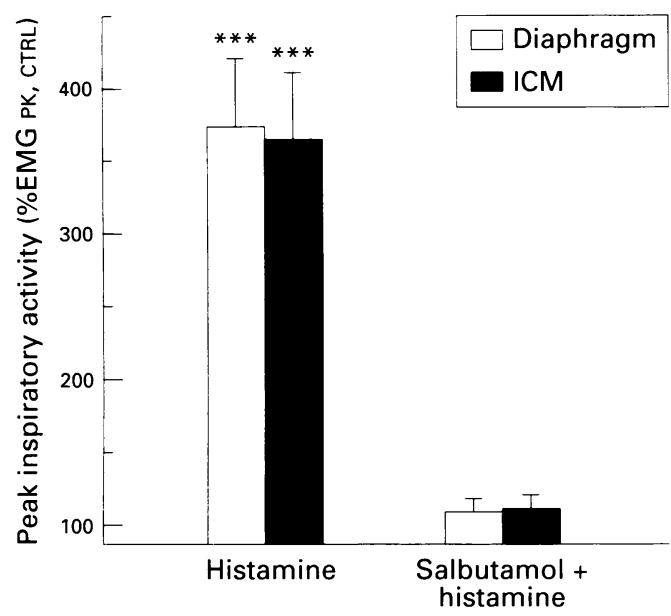

Figure 5 Effects of inhalation of histamine on peak inspiratory EMG activity in the diaphragm and intercostal muscles (ICM). Peak EMG activity is expressed as a percentage of mean peak inspiratory EMG activity of corresponding control breaths. After inhalation of $600 \mu \mathrm{g}$ salbutamol the effects of histamine on peak inspiratory EMG activities are abolished. Data represent means obtained from 21 subjects. Error bars indicate 1 $S E ._{* * *}^{*}<0.001$ compared with control values (Wilcoxon's test for paired observations).

Table 3 Mean (SE) responses of ETIA, FRC, and FEV to histamine in a group of subjects with no significant decrease in $F E V_{1}$ in response to histamine after salbutamol inhalation $(n=9)$

\begin{tabular}{llc}
\hline & Before salbutanol & After salbutamol \\
\hline ETIADI(\%) & $77.6(14.4)^{* *}$ & $31.9(6.5)$ \\
ETIAICM(\%) & $49.9(11.9)^{*}$ & $17.7(4.9)$ \\
$\Delta$ FRC $\left(\%\right.$ FRCpred) $_{\text {FEV }}(\%$ control) & $15.6(3.7)^{* *}$ & $2.0(0.9)$ \\
\hline
\end{tabular}

ETIADI, ETIAICM = end tidal inspiratory activity in the diaphragm and intercostal muscles; $\mathrm{FRC}=$ functional residual capacity; $\mathrm{FEV}_{1}=$ forced expiratory volume in one second. ${ }^{*} \mathrm{p}<0.05 ;{ }^{* *} \mathrm{p}<0.01$ before versus after salbutamol (Wilcoxon's test). ETIA in the diaphragm was significantly $(\mathrm{p}<0.05)$ higher than in the intercostal muscles for both conditions.

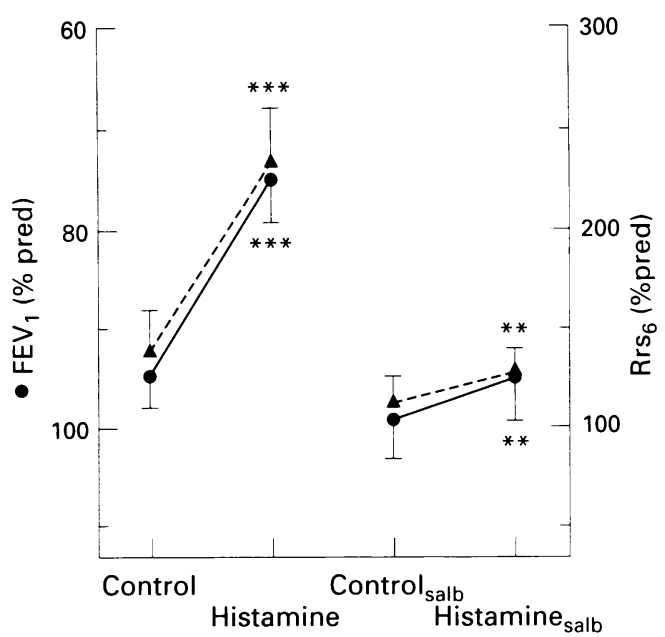

Figure 6 Responses of forced expiratory volume in one second $\left(F E V_{1} ; \mathrm{O}\right)$ and respiratory resistance at $6 \mathrm{~Hz}$

$\left(R r s_{6} ; \boldsymbol{\Delta}\right)$ as percentage predicted in response to histamine before and after inhalation of $600 \mu \mathrm{g}$ salbutamol. Before inhalation of salbutamol Rrs increased and FEV $_{1}$ decreased significantly in response to histamine compared with control. After inhalation of salbutamol these responses to histamine were much diminished. Data represent means obtained from 21 subjects. Error bars indicate $1 S E$. ${ }^{* * *} p<0.001 ; * * p<0.01$ (Wilcoxon's test for paired observations). Note inverse scale for $F E V_{1}$.

2, fig 4). After salbutamol peak inspiratory EMG activity did not change significantly in response to histamine being 109 (10)\% and 110 (11) $\%$ of $\mathrm{EMGpk}_{\mathrm{CTRL}}$ of the same recording for the diaphragm and intercostal muscles, respectively (fig 5).

EFFECTS OF HISTAMINE AND SALBUTAMOL ON RESPIRATORY RESISTANCE AND FEV ${ }_{1}$ Changes in airway diameter will influence respiratory resistance at $6 \mathrm{~Hz}\left(\mathrm{Rrs}_{6}\right)$ and $\mathrm{FEV}_{1}$. Effects of histamine on $\mathrm{Rrs}_{6}$ and $\mathrm{FEV}_{1}$ obtained from 21 subjects before and after inhalation of salbutamol are shown in table 2 and fig $6 . \mathrm{Rrs}_{6}$ increased significantly $(p<0.001)$ in response to histamine compared with control. After salbutamol only a small increase in $\mathrm{Rrs}_{6}$ was found in response to histamine compared with control values after salbutamol (fig 6). $\mathrm{FEV}_{1}$ decreased significantly compared with control values $(\mathrm{p}<0.001)$ in response to histamine (table 2, fig 6). After salbutamol a small but still significant $(p<0.01)$ fraction of that response remained (table 2, fig 6).

For further interpretation of the results a subgroup was defined including only those subjects whose $\mathrm{FEV}_{1}$ decreased by less than $2 \%$ in response to histamine after salbutamol. The mean values of ETIA, $\triangle F R C$, and $\mathrm{FEV}_{1}$ for this subgroup are presented in table 3 .

\section{Discussion}

Inhalation of histamine evoked ETIA in the diaphragm and intercostal muscles in all of our subjects. After administration of salbutamol the magnitude of histamine induced ETIA was considerably diminished. Similarly, FRC increased significantly in response to histamine, while this increase was minimal after sal- 
butamol. $\mathrm{FEV}_{1}$ decreased and $\mathrm{Rrs}_{6}$ increased in response to histamine. After salbutamol, inhalation of histamine only slightly affected these indices of bronchoconstriction.

\section{EMG AND SURFACE ELECTRODES}

It has been reported that the electrical activity of the diaphragm detected by surface electrodes is comparable with that detected by oesophageal electrodes ${ }^{23-25}$ and it is concluded that there is only a minimal contamination from the activity of other chest muscles. In man electrical expiratory activity was found in the transversus abdominis muscle but not in the external oblique or the rectus abdominis muscles during expiration. ${ }^{26}$ It is not likely, therefore, that the EMG of the diaphragm detected by surface electrodes is contaminated by electrical activity of abdominal muscles during expiration. Furthermore, the relationship between surface and oesophageal EMGs has not been found to be modified by changes in lung volume. ${ }^{2527}$ Contamination of inspiratory EMGs by expiratory activity is unlikely since our results for the EMGs of the diaphragm and intercostal muscles (figs 3 and 5) were comparable and were qualitatively the same as those found in our experiments in animals ${ }^{2}$ in which we used intramuscular electrodes. The use of surface electrodes to record EMGs of the diaphragm and intercostal muscles during the experimental conditions used in this study therefore appears valid.

\section{INDICES OF BRONCHOCONSTRICTION}

Several pulmonary function variables can quantify the patency of the airways. $\mathrm{FEV}_{1}$ decreases with increasing bronchoconstriction. It has been shown that $\mathrm{Rrs}_{6}$ is increased in patients with chronic obstructive pulmonary disease (COPD) and with asthma. ${ }^{22}$ The changes in $\mathrm{FEV}_{1}$ and $\mathrm{Rrs}_{6}$ in response to histamine and after salbutamol were as expected (table 2, fig 6). After salbutamol these indices reached values which were not different from pre-salbutamol control values or even "better". $\mathrm{FEV}_{1}$ decreased significantly in response to histamine even after inhalation of salbutamol (table 2, fig 6). Thus, histamine induced bronchoconstriction was not fully prevented by salbutamol although mean values of $\mathrm{FEV}_{1}$ after histamine ( $94.8 \%$ predicted) were comparable with pre-salbutamol control values $(94.7 \%$ predicted). Furthermore, changes in $\mathrm{FEV}_{1}$ and $\mathrm{Rrs}_{6}$ were very similar with respect to administration of histamine and salbutamol (fig 6).

\section{PEAK INSPIRATORY EMG ACTIVITY}

Peak EMG activity was increased significantly in response to histamine (about 3.5 times control values). This may have been due to a delayed off switch of inspiration because of increased airway resistance as well as to enhanced stimulation of inspiratory activity by airway receptors. This is supported by the observation that the increased peak EMG activity was no longer observed after bronchoconstriction had been prevented by salbutamol. Furthermore, mean minute ventilation after administration of histamine $(8.7(0.5) 1 / \mathrm{min})$ was not significantly different from control values (8.1 (0.5) $1 / \mathrm{min})$. Hence, changes in peak EMG activity cannot be attributed to changes in arterial carbon dioxide tension.

\section{END TIDAL INSPIRATORY ACTIVITY}

It has been shown that histamine can induce ETIA in rabbits, ${ }^{1}$ cats, ${ }^{2}$ and man. ${ }^{414}$ In a previous study in cats we have shown that stimulation of rapidly adapting pulmonary receptors elicits ETIA, whereas ETIA is inhibited by stimulation of slowly adapting receptors. ${ }^{25}$ Histamine induced bronchoconstriction is caused both by stimulation of $\mathrm{H}_{1}$ receptors in bronchial smooth muscles and by stimulation of rapidly adapting pulmonary receptors via a vagal reflex. ${ }^{28} 29$ In animals the activity of rapidly adapting pulmonary receptors has been found to be increased in response to inhalation of irritant gase ${ }^{30}$ and by intravenous or intratracheal application of histamine. ${ }^{89}$ It has been shown in dogs that when histamine is administered at intervals of longer than 15 minutes the responses of rapidly adapting pulmonary receptors are reproducible. ${ }^{31}$ In the further discussion we start from the assumption that the underlying mechanisms of ETIA in man are similar to those found in experimental animals summarised above.

The present study shows that inhalation of histamine is a powerful stimulus for inducing ETIA, both in the diaphragm and in intercostal muscles in man. After inhalation of salbutamol histamine induced ETIA was considerably reduced, indicating that bronchoconstriction was involved in causing ETIA and, by extrapolation of the abovementioned findings obtained in experimental animals, this would mean that the enhanced ETIA after administration of histamine is mainly due to mechanical stimulation of rapidly adapting pulmonary receptors by bronchoconstriction. This will be discussed in more detail below. Slowly adapting receptors are stimulated by increased lung volume, so if stimulation of slowly adapting receptors also inhibits ETIA in man, histamine induced hyperinflation may diminish the magnitude of histamine induced ETIA through rapidly adapting receptors.

After administration of salbutamol + histamine, $\mathrm{FEV}_{1}$ and $\mathrm{Rrs}_{6}$ reached levels which did not differ from their control values before salbutamol ( $p=0.71$ and 0.69 , respectively). This suggests that the remaining ETIA after salbutamol + histamine is due to direct chemical stimulation of rapidly adapting receptors. After salbutamol, however, a small but significant decrease in $\mathrm{FEV}_{1}$ and increase in $\mathrm{Rrs}_{6}$ (compared with control salb$_{\text {) were still observed }}$ in response to histamine (fig 6). Thus, it cannot be ruled out that after salbutamol some mechanical stimulation of rapidly adapting receptors by histamine induced bronchoconstriction was still present. In the results a subgroup of nine subjects was defined. The $\mathrm{FEV}_{1}$ in these sub- 
jects decreased in response to histamine before salbutamol. After salbutamol, however, there was no significant decrease in $\mathrm{FEV}_{1}$ in response to histamine compared with control salb $_{\text {(table }}$ 3). Values of ETIA after salbutamol + histamine should therefore be attributed to chemical stimulation of rapidly adapting receptors in these subjects. The mean values of histamine induced ETIA in these nine subjects were $41 \%$ and $36 \%$ of their pre-salbutamol values for the diaphragm and intercostal muscles, respectively. Thus, chemical stimulation of rapidly adapting receptors contributed for somewhat more than one third of the magnitude of ETIA. Hence, we may conclude that mechanical stimulation of rapidly adapting receptors by contraction of bronchial smooth muscles was the more important stimulus in histamine induced ETIA before salbutamol in this subgroup. That ETIA can be induced by mechanical stimulation of rapidly adapting receptors is in accordance with our previous findings that continuous negative airway pressure (CNAP) - which is a strong mechanical stimulus for rapidly adapting receptors - induces ETIA in cats ${ }^{5}$ and in man. ${ }^{32}$

The contribution of chemical stimulation to the total stimulation of rapidly adapting receptors may depend on the concentration of histamine used. In subjects with bronchial hyperresponsiveness a low dose of histamine causes a firm bronchoconstriction with corresponding mechanical stimulation of rapidly adapting receptors but, because of the low histamine concentration, chemical stimulation of the receptors may be small. The $\mathrm{PC}_{20}$ of eight of our nine subjects in the subgroup discussed above was $\geq 8 \mathrm{mg} / \mathrm{ml}$ histamine, thus the concentration of histamine administered to these subjects was rather high (mean 12.5 (1.9) $\mathrm{mg} / \mathrm{ml}$ ). In the remaining 12 subjects the concentration was lower (mean $9.68(2.03) \mathrm{mg}$ / $\mathrm{ml}$ ). It is likely, therefore, that the conclusion derived from the subgroup of the nine nonresponsive subjects will also apply to the responsive subjects - namely, that mechanical stimulation of rapidly adapting receptors is the more important stimulus in histamine induced ETIA.

The properties of rapidly adapting receptors suggest a positive feedback mechanism as stimulation of the receptors induces reflex bronchoconstriction which in turn stimulates the receptors. However, the concomitant increases in ETIA and flow limitation result in an increase in FRC which is beneficial by increasing the diameter of the airway.

\section{ETIA AND HYPERINFLATION}

In asymptomatic asthmatic subjects the end expiratory pleural pressure has been shown to be more negative during histamine induced hyperinflation than can be accounted for by the chest wall relaxation pressure, indicating the presence of ETIA. ${ }^{14}$ Therefore, in addition to airflow limitation ETIA may be one of the causes of hyperinflation. As mentioned before, after administration of salbutamol + histamine the $\mathrm{FEV}_{1}$ and $\mathrm{Rrs}_{6}$ reached levels which were comparable to their pre-salbutamol control values. It is likely, therefore, that the small histamine induced increase in FRC after salbutamol (table 2, fig 4) is solely due to ETIA which is also small in that condition (fig 3). Siafakas et $a l^{33}$ showed that there is a close proportional relationship between phrenic activity and the driving pressure of the respiratory system during inspiration. In static respiratory conditions this pressure is linearly related to lung volume in the middle of the range. ${ }^{34}$ In quiet breathing, as occurred in our experiments, static conditions are approximated at the turning points of inspiration and expiration. The findings of Siafakas et al suggest that, in control conditions with quiet breathing restricted to the mid-range of lung volumes, tidal volume (VT) is proportional to peak EMG activity and, further, that ETIA alone may account for an increase in FRC equal to ETIA times $V_{T_{C T R L}}\left(\Delta F R C=E T I A . V_{T_{C T R L}}\right)$. Note that ETIA is expressed as a percentage of EMGpk $\mathrm{CTRL}_{\mathrm{CTR}}$. Computation of this product for the total group of 21 subjects using the mean values of ETIA for the diaphragm and intercostal muscles resulted in the following estimated values for $\triangle F R C$ for ETIA alone: 328 (55) $\mathrm{ml}$ for the experiments before salbutamol and $90(24) \mathrm{ml}$ for the experiments after salbutamol. A comparison of these data with those measured for $\triangle F R C$ (table 2) suggests that the contribution of ETIA to histamine induced hyperinflation in our experiments is larger than that of flow limitation before salbutamol and that ETIA is the sole determinant of hyperinflation after salbutamol, which is consistent with the absence of flow limitation in that condition.

This study was supported by the Netherlands Asthma Foundation (NAF-88.26).

1 Badier M, Jammes Y, Romero-Colomer P, Lemerre C. Tonic activity in inspiratory muscles and phrenic motoneurons by stimulation of vagal afferents. $\mathcal{F}$ Appl Physiol 1989;66: by stimulat

2 Meessen NEL, Grinten van der CPM, Folgering HTM Luijendijk SCM. Histamine-induced end-tidal inspiratory activity and lung receptors in cats. Eur Respir $\mathcal{F} 1995 ; 8$ : $2094-103$.

3 Martin JG, Habib M, Engel LA. Inspiratory muscle activity during induced hyperinflation. Respir Physiol 1980;39:303 13.

4 Muller N, Bryan AC, Zamel N. Tonic inspiratory muscle activity as a cause of hyperinflation in histamine-induced asthma. F Appl Physiol Respirat Environ Exercise Physiol 1980;49:869-74.

5 Meessen NEL, Grinten van der CPM, Folgering HTM, Luijendijk SCM. Tonic activity in inspiratory muscles during continuous negative airway pressure. Respir Physiol during continuous

6 Armstrong DJ, Luck JC. A comparative study of irritant and type J receptors in the cat. Respir Physiol 1974;21: $47-60$

7 Vidruk EH, Hahn HL, Nadel JA, Sampson SR. Mechanisms by which histamine stimulates rapidly adapting receptors in dog lungs. $\mathcal{f}$ Appl Physiol Respirat Environ Exercise Physio 1977;43:397-402.

8 Mills JE, Sellick H, Widdicombe JG. Activity of lung irritant receptors in pulmonary microembolism, anaphylaxis and drug-induced bronchoconstrictions. f Physiol (Lond) 1969;203:337-57.

9 Dixon M, Jackson DM, Richards IM. The effects of histamine, acetylcholine and 5-hydroxytryptamine on lung mechanics and irritant receptors in the dog. $f$ Physiol (Lond) $1979 ; 287: 393-403$.

10 Dixon $M$, Jackson DM, Richards IM. The effects of $H_{1}$ and $\mathrm{H}_{2}$ receptor agonists and antagonists on total lung and $\mathrm{H}_{2}$ receptor agonists and antagonists on total lung resistance, dynamic lung compliance and irritant receptor
discharge in the anaesthetized dog. Br $f$ Pharmacol 1979 ; discharge in

11 Shore SA, Bai TR, Wang CG, Martin JG. Central and local cholinergic component of histamine-induced bronchoconstriction in dogs. $\mathcal{F}$ Appl Physiol 1985;58:443-51. 
12 Matsumoto S. Effects of ammonia and histamine on lung irritant receptors in the rabbit. Respir Physiol 1989;77: 301-8

13 Woolcock AJ, Rebuck AS, Cade JF, Read J. Lung volume changes in asthma measured concurrently by two methods. Am Rev Respir Dis 1971;104:703-9.

14 Martin JG, Powell E, Shore SA, Emrich J, Engel LA. The role of respiratory muscles in the hyperinflation of bronchial asthma. Am Rev Respir Dis 1980;121:441-7.

15 Woolcock AJ. Asthma what are the important experiments? Am Rev Respir Dis 1988;138:730-44.

16 Demedts M. Mechanisms and consequences of hyperinflation. Eur Respir f 1990;3:617-8.

17 Cockcroft DW, Killian DN, Mellon JJA, Hargreave FE. Protective effect of drugs on histamine-induced asthma. Thorax 1977;32:429-37.

18 Phillips GD, Finnerty JP, Holgate ST. Comparative effect of the inhaled beta $2_{2}$ agonist salbutamol (albuterol) on bronchoconstriction provoked by histamine, metacholine, and adenosine $5^{\prime}$-monophosphate in asthma. 7 Allergy Clin and adenosine 5-monophosp

19 Hargreave FE, Ryan G, Thomson NC, et al. Bronchial responsiveness to histamine or methacholine in asthma: measurement and clinical significance. $\mathcal{F}$ Allergy Clin Immunol 1981;68:347-55.

20 Quanjer $\mathrm{PhH}$, ed. Standardized lung function testing. Report of Working Party on Standardization of Lung Function Tests. Bull Eur Physiopathol Respir 1983;19(Suppl): $1-95$.

21 Landser FJ, Nagels J, Demedts M, Billiet L, Van de Woestijne KP. A new method to determine frequency characteristics of the respiratory system. F Appl Physiol 1976; 41:101-6.

22 Clement J, Landser FJ, Van de Woestijne KP. Total resistance and reactance in patients with respiratory complaints with and without obstruction. Chest 1983;2: 215-20.

23 Gross D, Grassino A, Ross WRD, Macklem PT. Electromyogram pattern of diaphragmatic fatigue. $₹ \mathrm{Appl}$ Physiol Respirat Environ Exercise Physiol 1979;46:1-7.
24 Sieck GC, Mazar A, Belman MJ. Changes in diaphragmatic EMG spectra during hyperpneic loads. Respir Physiol 1985

25 Scano G, Duranti R, Spinelli A, Gorini M, Lo Conte C, Gigliottie F. Control of breathing in normal subjects and in patients with chronic airflow obstruction. Bull Eur Physiopathol Respir 1987;23:209-16.

26 Ninane V, Rypens F, Yernault J-C, De Troyer A. Abdominal muscle use during breathing in patients with chronic airflow obstruction. Am Rev Respir Dis 1992;146:16-21.

27 Banzett RB, Inbar GF, Brown R, Goldman M, Rossier A Mead J. Diaphragm electrical activity during negative lower torso pressure in quadriplegic men. 7 Appl Physiol Respirat Environ Exercise Physiol 1981;51:654-9.

28 Barnes PJ. Neural control of airway smooth muscle. In Crystal RG, West JB, Barnes PJ, Cherniack NS, Weibel ER a s. The lung: Scientific foundations. New York: Raven Press, 1991:903-16.

29 Barnes PJ. Pharmacology of airway smooth muscle. In Crystal RG, West JB, Barnes PJ, Cherniack NS, Weibel ER, eds. The lung: Scientific foundations. New York: Raven ER, eds. The lung: Sci

30 Davies A, Roumy M. A role of pulmonary rapidly adapting receptors in control of breathing. Aust f Exp Biol Med Sci 986;64:67-78.

31 Sampson SR, Vidruk EH. The nature of the receptor mediating stimulant effects of histamine on rapidly adapting vagal afferents in the lungs. $f$ Physiol (Lond) 1979;287 509-18.

32 Meessen NEL, Grinten van der CPM, Luijendijk SCM Folgering HTM. Continuous negative airway pressure increases tonic activity in the diaphragm and intercostal muscles in humans. 7 Appl Physiol 1994;77:1256-62.

33 Siafakas NM, Chang HK, Bonora M, Gauthier AP, MilicEmili J, Duron B. Time course of phrenic activity and respiratory pressures during airway occlusion in cats. Appl Physiol Respirat Environ Exercise Physiol 1981:51: 99-108.

34 Agostoni E, Hyatt RE. Static behavior of the respiratory system. In: Macklem PT, Mead J, eds. Handbook of physi. The respiratom sys, Mead J, eds. Handbook of physBethesda: American Physiological Society, 1986:113-30. 